\title{
INTRA-EU MOBILITY: THE EMPLOYMENT AND WELFARE EXPERIENCE OF TEMPORARY EU WORKERS IN THE UNITED KINGDOM
}

\author{
Sonila DANAJ', Erka ÇARO"
}

COBISS 1.01

\section{ABSTRACT \\ Intra-EU Mobility: The Employment and Welfare Experience of Temporary EU Workers in the United Kingdom}

This article explores the mobility pathways of temporary EU workers and the implications that transnational temporary mobility has on their labor market outcomes and access to social rights and benefits. The experiences of temporary EU migrants working in the UK show that despite the narrative of the borderlessness of the common European labor market, access to host countries' labor market and welfare is shaped by their employment status and welfare eligibility criteria that produce worker precariousness. Temporary EU workers' experiences are characterized by employment insecurity and unequal access to labor and social rights, effects which might increase since the UK has left the EU.

KEYWORDS: European Union, temporary migrant workers, labor rights, social rights, United Kingdom

\section{IZVLEČEK}

\section{Mobilnost znotraj EU: Zaposlitvene in socialnozdravstvene izkušnje začasnih} delavcev iz EU v Veliki Britaniji

Članek obravnava mobilnost začasnih delavcev iz EU in vpliv transnacionalne začasne mobilnosti na njihov uspeh na trgu dela ter dostop do socialnih pravic in ugodnosti. Izkušnje začasnih migrantov iz EU na delu v Združenem kraljestvu kažejo, da je zanje dostop do trga dela in socialnega skrbstva v državi gostiteljici kljub deklarativni brezmejnosti evropskega trga dela odvisen od njihovega zaposlitvenega statusa in upravičenosti do socialne pomoči, kar vse vodi v delavsko prekarnost. V zvezi z dostopom do delavskih in socialnih pravic so izkušnje začasnih delavcev iz EU zaznamovane z zaposlitveno negotovostjo in neenakopravnostjo, ki se bosta zaradi izstopa Velike Britanije iz Evropske unije le še povečevali.

KLJUČNE BESEDE: Evropska unija, začasni migrantski delavci, delavske pravice, socialne pravice, Združeno kraljestvo

PhD candidate in sociology, University of Jyvaskyla; researcher, European Centre for Social Welfare Policy and Research, Berggasse 17, A-1090, Vienna; danaj@euro.centre.org; https://orcid.org/00000002-0582-7125.

\| $\quad$ PhD in population studies, University of Groningen; lecturer, Department of Geography, University of Tirana, Rruga e Elbasanit, Tirana; erkacaro@gmail.com; https://orcid.org/0000-00019183-9642. 


\section{INTRODUCTION 1}

The enlargement of the European Union (EU) has expanded the forms of intra-EU mobility (Ryan et al. 2009). Yet, the removal of borders has not led to the removal of all barriers to EU countries' national markets and welfare systems. Although EU citizens do not have to fulfill visa and work permit requirements like third-country nationals (Anderson 2010), they can still be quite precarious. Some companies and labor market intermediaries, like temporary work agencies, take advantage of the gaps in transnational, national and sectoral labor market regulations to differentiate between temporary EU workers and local workers or other categories of more permanent migrants (Alberti, Danaj 2017; Andrijasevic, Sacchetto 2016; Berntsen, Lillie 2015).

This article seeks to understand how the mobility pathways of temporary EU workers are shaped by their mobility motives and the way they access the host country's labor market by cross-fertilizing the industrial relations with migration and social welfare literature. It discusses the role and implications transnational regulations at the macro level that result in cross-border temporary mobility have on the labor market outcomes and access to social rights and benefits of EU workers as experienced at the micro-level. Our study is based on fifty-five in-depth interviews with temporary EU workers, social partners and managers in the United Kingdom (UK). We identify two main temporary migrant pathways: posted work and temporary agency work. We argue that despite the narrative of the borderlessness of the common European labor market, access to host countries' labor market and welfare is shaped by their employment status and national welfare eligibility criteria that manifest in different forms in the lived experiences of EU temporary migrant workers. The experiences of temporary EU workers are characterized by employment insecurity and unequal access to labor and social rights. Effects that might increase now that the UK has left the EU and the migration policy applicable to these workers could become as restrictive as that of other third-country nationals (Lindstrom 2019).

\section{TEMPORARY EU WORKERS IN THE EUROPEAN SINGLE MARKET}

EU citizens can freely navigate the European single market; however, their labor mobility is shaped by several EU and national regulations that aim to facilitate labor supply across the EU while protecting national standards. Hence, during the EU enlargement rounds of 2004 and 2007, some Member States placed restrictions on the freedom of movement of new members for a transitional period between two to five years (Fihel et al. 2015). Consequently, the range of moves within the European

1 This research was supported by the European Research Consortium [grant number TWES 263782]. 
Union expanded to multiple forms of mobility and temporary migration (Ryan et al. 2009). During the transition period, Central and Eastern European workers needed a work contract and permit to work in other EU countries. After the transition period, countries like Austria, Belgium or the UK continued to apply additional criteria to the right to reside by requiring EU workers to provide evidence of economic independence, criteria that have constrained many EU workers to accept unfavorable terms and conditions of employment and left them in a state of perpetual precarity (Alberti 2016; Dwyer et al. 2019; Shutes 2016).

Various EU directives regulate intra-EU mobility and labor market demands for temporary labor, such as the Posting of Workers Directive (PWD) $(96 / 71 / E C)$ and the Temporary Agency Work Directive (TAWD) (2008/104/EC). The PWD, which falls under the freedom to provide services, allows EU employers to bid for tenders in other Member States and "post," i.e., send their workers to execute the job. Once these posted workers finish delivering the service for which their company is subcontracted, they should return to their country. Posted workers, therefore, could be classified as temporary labor migrants or mobile workers who return home once their assignment is completed. Similarly, the TAWD regulates the employment relation of workers with a contract of employment with a temporary-work agency temporarily assigned to user companies. The lines dividing these categories of workers are often blurred, as their contractual arrangements shift continuously between being posted to being hired by a temporary work agency and at times also posted by a temporary work agency (Alberti, Danaj 2017). While their contractual arrangements might be shifting and overlapping, the differentiating feature is how they move to the host country, i.e., their labor mobility pathways. In this article, those sent to the UK to provide a service temporarily by a company or an employment agency are referred to as posted workers and those who moved to the UK on their own and eventually found employment through UK-based temporary employment agencies as agency workers.

In the migration literature, EU citizens' migration type is explained through the available macro structures and opportunities and through their individual motivations (Coletto, Fullin 2019). Their mobility pathways influence their labor market behavior, with some migrant workers finding ways to reconcile employment opportunities at home and abroad to sustain repeat migration (Fihel, Grabowska Lusinska 2014), while others frequently move within the host country labor market aiming for upward mobility (Alberti 2014). The mobility pathway influences the level of protection that migrants receive. Both the PWD and the TAWD stipulate the right to minimum protection and equal terms and conditions for posted/agency workers. Nonetheless, inequalities among temporary EU mobile workers and direct employees exist; some employers use the gaps in the labor market regulatory frameworks to exploit lower-wage workers from lower-income countries (Andrijasevic, Sacchetto 2016; Berntsen, Lillie 2015; Cremers 2011). As a result of these "regime shopping" practices (Houwerzijl 2014), found particularly in so-called low-skill, low-paid industries 
with subcontracting chains and a transnational workforce, such as construction, food processing and services, multiple violations of the labor rights of EU migrant workers have been identified (Andrijasevic, Sacchetto 2016; Cremers 2011).

Not only do employers exploit the flexibility of posted and agency migrant workers, but workers themselves use these migration pathways for their own motives (Lee 2009; Massey, Malone 2002). As McCollum and Findlay put it, "flexible labour markets create a structural demand for migrant labour and a ready supply of migrant labour allows flexible labour markets to flourish" (2015: 439). However, Lillie (2016), in the case of posted workers, and Andrijasevic and Sacchetto (2016), in the case of temporary agency workers, argue that the cross-border mobility of EU workers undermines any effective way for them to be free-market agents able to negotiate their position with the employers.

The pathways they undertake influence EU workers' access to social rights as precarious temporary EU workers have limited or no access to the host country welfare system (Alberti 2016; Heindlmaier, Blauberger 2017; Marques et al. 2021). EU migrants are often unaware of their social rights and would rather seek solutions privately or in their home country than try to access the host country's welfare system (Ehata, Seeleib Kaiser 2017; Godin 2020). Temporariness, spatial segregation, and the lack of a sense of belonging experienced by temporary migrant workers disrupts their integration process in the host country (Çaro et al. 2015). Social benefits are conditioned by the period a migrant worker has paid social contributions to the host country's welfare system. Only with time do migrants become more familiar with host country rules and entitlements (Pemberton, Scullion 2013).

\section{METHODOLOGY}

This article analyzes the working and welfare experiences of two types of EU workers in the UK: posted and agency workers. We adopted a qualitative approach based on in-depth interviews (Wengraf 2001). Our analysis is based on fifty-five interviews: fifteen posted and fifteen agency workers, fifteen workplace representatives, four trade union officials and senior organizers, five managers, and one employer organization representative conducted during 2014-2015. Informants were recruited through a combination of several contacts or "gatekeepers" in the host country, such as trade unions and other mediators (Refslund 2019), with the snowball technique. We interviewed Spanish, Polish, Romanian, Irish, Latvian, Lithuanian, Czech, Bulgarian, and Slovakian workers employed in the construction, food processing/ packaging, and retail industries in Northern England. The posted workers worked in construction: most had spent less than half a year in the UK. Six of them had been posted more than once to the UK, and during their last posting, four of them had also been employed by an agency. The agency workers had lived in the UK for between one to ten years. Some of them had worked in various industries and workplaces 
employed through several employment agencies, whereas others were employed by in-house agencies to work in the same workplace, e.g., the food processing factory. Most posted and agency workers had previously worked in other EU countries, predominantly Germany, the Netherlands, France, and Italy.

The interviews consisted of semi-structured questions on the informants' socioeconomic background and open-ended questions about the migrant workers' recruitment and employment experiences as well as their access to social protection. This article considers mobile EU workers as both migrants and workers (Alberti et al. 2013) by considering their statuses as temporary migrants and precarious workers. The analytical approach is that of methodological transnationalism (Amelina, Faist 2012), which focuses on the dynamics of cross-border labor mobility to understand the level of access to labor and social rights of temporary EU workers.

\section{POSTING AND AGENCY WORK IN THE UK}

The UK transposed the PWD simply by removing jurisdiction clauses and including posted workers in its labor legislation. Since then, it has been among the main receiving countries for posted workers attracting around 50,000 posted workers yearly (De Wispelaere, Pacolet 2018), mainly from Eastern and Southern Europe. The use of posted workers corresponds to a growing demand for labor and specific skills, particularly in the construction sector, which has seen an increase in the number of large-scale construction projects as a result of changes in the UK's emissions legislation (which has led to the closure of several old power plants and the commission of new ones) as well as an aging workforce. Thus, posted workers during our fieldwork were found in large construction sites, where the subcontracting chain reached up to twenty-seven companies, both foreign and domestic, all operating simultaneously. Posted workers were usually found at the end of the subcontracting chain hired by the companies that were executing parts of the project. Most of them were employed by engineering construction companies in jobs like welders or fork lifters, and a few in civil engineering construction, specializing in the operation of heavy machinery. As a result of the National Agreement for Engineering Construction Industry (NAECI 2013-2015), posted workers in these construction sites constituted twenty percent of the total workforce on-site or 100-120 posted workers in workplaces of 500-600 workers.

Agency work, on the other hand, focuses on the temporary service provision and the supply of a flexible labor force. Its regulation has been negotiated at both the national level and at the EU level. The UK passed the TAWD only after a bilateral agreement between trade unions and employer associations was reached on a period of twelve weeks of flexibility before granting agency workers equal treatment, which was also included in the 2008 EU Directive and their national Agency Work Regulation of 2010. A myriad of contractual arrangements is used by temporary 
work agencies that aim to circumvent regulations creating different statuses and categories for agency workers and making estimates on their numbers in the British labor market complicated (Forde and Slater 2014). Estimates based on the definition of agency workers as someone who provides services in a workplace but is contracted by an intermediate agency indicate growing numbers in the last five years up to 950,000 in 2018 (Clarke, Cominetti 2019), more than half in the construction sector, followed by wholesale and retail, business and hospitality (Judge 2018). Although it is not clear how many of these agency workers are migrants, their share is considered to vary between 70 to 100 percent depending on the region (Association of Labour Providers 2016).

The temporary agency workers interviewed worked in different low-skill, lowwage industries, mainly food processing, packaging and retail, but they had previous temporary work experience in construction, agriculture, cleaning, and other services. Two types of temporary work agencies recruited them. The first kind were in-house agencies, which were exclusively working for one company with offices located in the workplace and which recruited temporary workers on behalf of the employer for a period of three months to one year or more before some of these workers were offered direct employment. The second type were temporary work agencies that recruited workers for various user companies.

\section{TEMPORARY EU WORKERS' PATHWAYS}

EU citizens can move freely between the Member States and seek employment opportunities within the common European market, including the UK. Despite this freedom of mobility, their migration pathways are shaped by their migration motives, the way they access the host country's labor market, and the sectors in which they are employed. This research focused on temporary EU workers to the UK employed in so-called low-skill, low-wage industries, and we identified two main pathways, namely posted work and temporary agency work.

Our findings indicate that not all EU workers intend to migrate. Posted work as a pathway is chosen because mobility is temporary and provides the opportunity to maintain continuous employment with home-based employers. Sectors like construction are project-based and the construction workers interviewed were commonly employed under open-ended discontinuous contracts. To be paid continuously, workers under such contracts routinely accept assignments across their own country or abroad. As posted workers, they could come to another EU country for a defined period on assignment and return to their home country once the job is finished. This arrangement made temporary mobility acceptable because it allowed workers to return home periodically during the posting assignment and altogether once that assignment was completed. Workers with families back home cherished such opportunities, as they did not want to leave in the first place but 
were constrained by lack of employment at home: "It is simply that you have to work and if your country does not give you work, you have to move to wherever. It is not fun to work outside your country, nor to work far from your home, but it is what you get" (Hernández, Spanish posted worker, mechanic).

A few EU workers used posted work as a strategy to enter and navigate the host country labor market. They did not need to search for employment or arrange travel and lodge in a foreign country; the employer provided the work and made the necessary travel and accommodation arrangements. Most workers interviewed moved as a team from one construction site to another, making it easier to relocate, especially for non-English speakers. Four Spanish posted workers told us about their plans to undergo the local skill certification process, apply and be hired by a British company, which they eventually did. Once they became familiar with the local labor market and established contacts and/or a network, they were, thus, able to navigate the British labor market, quit the posting job, and find direct and more long-term employment with a UK-based employer.

EU workers that chose the pathway of temporary agency work, on the other hand, all intended to migrate. They had moved to the UK, either in search of better employment opportunities or to join their families. Upon arrival, they sought ways to access the British labor market and contacted temporary work agencies through friends or the internet. Few agency workers intended employment abroad to be temporary, just to earn some money and return home to their families. One hypermobile agency worker told us about his temporary labor mobility from Poland to multiple EU countries such as France, Italy, Luxembourg, Netherlands, UK, doing diverse jobs in different sectors. Despite their skills, interviewed temporary agency workers were all employed in so-called low-skill, low-wage industries, such as food processing/packaging and retail industries and had also worked in construction, agriculture, cleaning, and other services.

Most agency workers, like the Spanish posted workers mentioned above, used temporary work agencies as a stepping stone to enter the British labor market until they found long-term employment. For example, Jānis, a Latvian worker who had come to the UK eight years earlier, had found his first job via a temporary work agency serving food in a hospital, then he found an hourly paid job via an in-house agency in a food factory, and after working there for two years was offered a full-time permanent job.

\section{TEMPORARY EU WORKERS' LABOR RIGHTS}

Posted workers and temporary agency workers are highly vulnerable to exploitation. The combination of temporariness with cross-border mobility and low-skill, low-wage employment situates them into the most precarious segment of the host country's labor market, where labor rights are not always protected. 
In the case of posted work, foreign subcontractors operating in the UK or elsewhere in the EU have used the competitive advantage of employing workers from lower-income countries to provide services at lower costs by paying posted workers less than local workers (Berntsen, Lillie 2015; Cremers 2011). Several workers reported being paid less than local workers in the first site, even though both sites were operating under CBA pay rates and workplace trade union representatives actively worked to enforce equal terms and conditions across the subcontracting chain. Workers posted in the same site also reported other irregularities such as double books: "This [Spanish] company wanted to work here in the UK because Spain is going through bad times [...] They told me to open a British and a Spanish bank account [...] One for taxed money and the other for black money. [...] So, we would receive part of the salary in black" (Cervantes, Spanish posted worker, welder).

The same company eventually did not pay their workers for fifty days. Posted workers struggled to have their rights enforced until they sought the support of the unions in the workplace. Their company was eventually fired from the project, and the workers were re-hired by another subcontractor, who paid them properly. A Slovenian worker working for another subcontractor in the same site was not so "lucky." He also reported his employer to the trade unions in the workplace for underpaying him and his colleagues. He soon after left the workplace, officially resigning. There was a strong suspicion that the worker was pressured to quit.

Fear of employer retaliation was mentioned by participants and confirmed by trade unions, who told us that posted workers were often faced either implicitly or explicitly with the pressure to comply with poorer terms and working conditions under the threat of losing their jobs, suggesting they are quite vulnerable in their dependence to their posting employers. These companies are the main, if not the only employer back home, which makes workers' dependency higher. As Cervantes explained: "[...] They [workers] are afraid of being fired because in Spain there are no jobs. [...] So, they are afraid of losing their jobs." Even when some workers overcome the fear of job loss by reporting the companies and asking for trade union support to achieve equal pay, the outcome is not always in their favor as the experience of the Slovenian posted worker mentioned earlier illustrates, which might also explain why some posted workers decide not to claim their labor rights. In other words, their temporary employment abroad and their continuous employment relation with the posting employer both abroad and at home increases their vulnerability and leaves them in a situation of perpetual precarity.

Even in the case of temporary agency workers, there are high levels of precarity. Despite their wish to move from temporary to standard employment, the shift, when it happens, is possible after long periods of time. Some were still employed as temporary agency workers, and all those who had eventually received one-year or permanent contracts did not shift to the more standard contractual arrangements right after the legally required twelve weeks of working for the same user company, but at least a few months if not one or two years later. The workers who had already 
received permanent contracts did not comment on the delay. A manager we interviewed in a food factory said that they rely on temporary agency work when there is a need but also strategically to cover extensively or exclusively certain roles (cf. Judge 2018). Longer-term employment was offered to a few after extended periods of temporary work and after they demonstrated their "skills and commitment":

Some people are on the agency for longer because it takes longer for them to catch up or be able to do the same job as other people. But everyone gets the opportunity to show, and the majority of the time, they do get up to that standard because everyone wants a permanent job. [...] Obviously, the people that have been here the longest would like to be rewarded with a permanent job. But sometimes, they just need to show that little bit of effort that is needed. (British food factory manager)

Both temporary agency workers and user companies use recruitment via temporary agencies as a steppingstone to direct employment; however, user companies also use the flexibility provided by temporary agency work to meet their needs without necessarily delivering on the promise of direct employment, which puts temporary agency workers in an unsecure position.

There is an important difference between in-house agencies and the ones that provide temporary services to multiple user companies. Workers recruited by inhouse agencies were more likely to be eventually hired directly by the user company than the others. In the first case, the relation between the workers and the agency was more exclusive, terms and conditions were commonly respected. They also assisted with workers' transition to direct employment. In the second case, workers' relation with the temporary agencies was quite weak. Sometimes they had registered with more than one agency and accepted temporary employment with whoever would offer work first.

The second category of temporary agency workers also had more issues with underpayment or delays in receiving their wages. One worker explained how he had not been paid for three weeks and was obliged to request the Citizens Advice Bureau's assistance:

I just did not get my salary for two weeks, and it is the third week today ... All the time, they tell me, "we did not receive e-mail." [...] I spoke with the general manager [of the company] today, she showed me all the e-mails sent to the [temporary work] agency. After tomorrow till 8 o'clock, if I do not get money, I am going to Citizens Advice Bureau. I cannot pay rent - three weeks I am working for free. (Wojciech, Polish agency worker)

Another worker shared a more extreme experience with an agency that did not provide any contracts, paid minimum rates, deducted all expenses like travel, equipment, and work gear, informed him only one hour prior he had to go somewhere for 
work, and provided no support or directions, and if he was late, retracted the offer and did not pay him (Tomasz, Polish agency worker).

While issues with payments are perhaps the main labor right infringement for both posted and agency workers, they are also exposed to poorer working conditions and intensive long work schedules combined with the uncertainty of job duration (cf. Alberti, Danaj 2017; Vah Jevšnik, Rogelja 2018). Both posted and agency workers interviewed often did not know where they would be sent until the very last moment (for agency workers, sometimes early in the morning of the same day) or for how long they would be on each assignment. Long working days were also quite common. One posted worker told us he had been working sixty-eight hours and seven days a week (Czaykowski, Polish posted worker), several agency workers reported working twelve hours per day at times, and one worker reported having worked up to sixteen hours per day, "sometimes one [working] day is ten hours, sometimes sixteen hours, it is hard to say. Sometimes it is five days a week, sometimes seven" (Wojciech, Polish agency worker).

Posted and temporary agency workers in low-skill and low-wage industries who choose these temporary mobility pathways are exposed to high risks of exploitation. The experiences of the EU mobile workers are, thus, characterized by the dependence on the posting companies or the temporary work agencies for access to the host country's labor market, insecurity about the duration of their employment, and unequal terms and conditions.

\section{TEMPORARY EU WORKERS' WELFARE ACCESS AND SOCIAL RIGHTS}

The two pathways of posted work and temporary agency work diverge on the access to the host country's welfare system: EU posted workers are bound to the social protection system of the sending country, where they can exercise their social rights, whereas temporary agency workers should have access to the host country's welfare regime and exercise their social rights there.

Even though posted workers work in another country during the posting assignment, they continue to be covered by the social protection system and legislation of the EU country in which they habitually work (Regulation (EC) No 883/2004). During the posting assignment, workers' social contributions should continue to be paid in the home country; hence potential claims are also to be made in that country. Portable document $\mathrm{A} 1$ forms (PDs A1) evidence workers' affiliation to the social security system of the sending country. However, different EU Member States have different rules of issuing PDs A1 and sometimes it is enough for companies to submit within the fiscal year. Posted workers are not always aware of their right to this document, and sometimes they might accept the employer's claim that they continue to be covered by the social protection system at home without any guarantee contributions are actually paid. The industrial relations literature has already provided evidence of 
regulatory evasion or fraud, e.g., through letterbox companies or using the same PD A1 for various workers or multiple times (Berntsen, Lillie 2015).

Most posted workers find out whether their employers have paid social security contributions and the extent of their social protection only when they want to claim a benefit. The workers interviewed during the fieldwork were employed mainly by the same employer for several years. Therefore, they tend to know whether their employers were abiding by their social protection obligations. As one said:

Yes, everything is paid. I insist on that because you go home and there is no work, and you go to unemployment, you are $\mathrm{f}^{* * *}$ if it is not right. [...] The company I work for they are very good, it is all done, and it has to be done. [...] Your terms of employment tell you your basic rights and your holiday entitlements, sick pay, time off and all the usual stuff that goes into employment. And you sign the bottom of that, and it is like a contract. (Joyce, Irish posted worker 360 slew teleporter driver)

Workers were also aware of the limitations of their social protection while posted. When asked about paid holidays, all responded that they would go on holiday when the posting job was finished. Yet, for those on discontinuous contracts, that meant to go on unemployment benefits and unpaid holidays. During our fieldwork, we did not have any cases of injuries. The literature, however, informs of cases of unpaid social security contributions and health insurance, which have been discovered under grave circumstances, such as accidents at work, when workers had to personally cover medical expenses or were not entitled to disability benefit. (See Danaj, Zólyomi 2018; Vah Jevšnik, Rogelja 2018.)

Different from posted workers, agency workers' social security contributions were paid into the British welfare system. Yet, their access to welfare entitlements depended on the kind of temporary work agency they were recruited from and the period of their employment. Those working for an in-house temporary work agency did not have problems with payments of social contributions. The long-standing relationship between the company and the agency facilitated their access and protection of social rights. The above-mentioned Latvian worker who had shifted from temporary agency work to permanent employment, for example, said there was no difference to his social contributions between the period he was on an hourly paid contract and the permanent one.

However, EU migrant workers are not always aware of their social rights (Ehata, Seeleib-Kaiser 2017). This lack of awareness was the case for all agency workers interviewed. When asked about whether social security contributions were paid for them, two workers said that they did not know and, at the same time, dismissed the question as irrelevant. As one of them put it, "I do not know if I have got one [health insurance], I don't really care. I am healthy, I am alright, for now" (Ugne, Lithuanian food factory agency worker). The inattentiveness to social and health care contributions can be explained by the lack of knowledge of their entitlements combined 
with a lack of belongingness caused by their temporariness and hyper-mobility across borders and workplaces, which incline these workers to concentrate their efforts in making it in the host country labor market, rather than invest in institutional support in case they might not.

The less work temporary agency workers could do, the more limited their access to welfare was. Three temporary agency workers interviewed told us that there were times when they did not work enough hours to make a living and struggled to survive. Two had even been homeless for intermittent periods. They had not applied for or obtained any form of unemployment benefit and relied on friends, were homeless or returned home during that time. One of them eventually found a permanent job, which he lost due to lengthy health problems. Because of his full-time job, he was able to receive the job seeker's allowance and full housing benefits. Upon recovery, he became an agency worker again and applied for a change of address closer to work. However, the city council denied his request and revoked the housing benefit, which forced him to ask for support from the Citizens Advice Bureau (Wojciech, Polish agency worker). Wojciech's story demonstrates how vulnerable and insecure temporary EU workers can be, a circumstance that can only be exacerbated by the increasing conditionality criteria that restrict access to EU jobseekers from the new British Universal Credit system in the wake of Brexit (Dwyer et al. 2019).

Posted workers and temporary agency workers differ in their access to welfare. The former continues to be covered by the sending country legislation, while the second by the host country. Their experiences indicate that they are not always aware of their social rights and rely on the posting employers or temporary work agencies to abide by their social security obligations, whether in the home or host country. Longer periods of employment were perceived in both cases as a form of reliability on the employers' commitment to their obligations; however, the most transient and precarious workers were also most likely to be excluded from welfare support.

\section{CONCLUSION}

This article recounts the mobility pathways of temporary EU workers, namely, posted and temporary agency workers. It shows how individual motivations, temporariness, hyper-mobility and recruitment via labor market intermediaries in low-skill, lowwage industries affect migrants' labor market outcomes and access to social rights and benefits in the UK. For most posted workers, migration is not the aim, employment is, whereas, for the temporary agency workers, long-term or permanent stay in the host country is the objective. Our findings contribute to the literature that focuses on mobile workers' barriers and differential treatment (Alberti, Danaj 2017; Andrijasevic, Sacchetto 2016; Lillie 2016; Marques et al. 2021) by exposing temporary EU mobile workers' vulnerabilities in terms of their labor and social rights. 
Despite temporary EU migrant workers' willingness to accept flexible contractual arrangements (McCollum, Findlay 2015) and make the most of posting and temporary agency work as mobility pathways, our findings indicate this is a constrained choice dictated by the need to generate income, maintain ties with the home country, and access the host country labor market. Their temporary migration undermines any effective way to freely negotiate their position with the employers (Andrijasevic, Sacchetto 2016; Lillie 2016) and makes workers vulnerable to exploitation.

Their mobility pathways also condition access to welfare. Posted workers are covered by the sending country's legislation, whereas agency workers' access to the host country's welfare system depends on the duration of their employment. The more transient their employment and the less time they spent in the host country, the less access they have to social benefits. Temporary employment translates into a lack of attention to their social welfare status and limited knowledge and awareness about their labor and social rights (cf. Ehata, Seeleib Kaiser 2017).

This study was conducted when the UK was a full EU Member State. The experiences of temporary EU migrants working in low-skill, low-wage industries in the UK indicate that temporary mobility pathways such as posting and temporary agency work produce and sustain inequalities that strongly challenge the equal rights presupposition of EU citizenship (Berntsen, Lillie 2015; Marques et al. 2021). The UK's decision to leave the EU will further restrict worker mobility from EU countries under conditions similar to the point-based criteria applied to third-country nationals. Bilateral or framework agreements, perhaps in particular sectors, might lead to other forms of temporary mobility, such as seasonal work, circular migration, or a quotas system. These pathways might also lead to various forms of differentiation and discrimination, like those experienced by third-country nationals across the EU, which are considered a serious threat to labor standards for all workers in the country (Lindstrom 2019; Portes 2016).

\section{REFERENCES}

Alberti, Gabriella (2016). A New Status for Migrant Workers: Restrictions of the Free Movement of Labour in the EU. Mondi Migranti 3, 33-49.

Alberti Gabriella (2014). Mobility Strategies, 'Mobility Differentials' and 'Transnational Exit': The Experiences of Precarious Migrants in London's Hospitality Jobs. Work, Employment and Society 28/6, 865-881.

Alberti, Gabriella, Holgate, Jane, Tapia, Maite (2013). Organising Migrants as Workers or as Migrant Workers? Intersectionality, Trade Unions and Precarious Work. The International Journal of Human Resource Management 24/22, 4132-4148.

Alberti, Gabriella, Danaj, Sonila (2017). Posting and Agency Work in British Construction and Hospitality: The Role of Regulation in Differentiating the Experiences of Migrants. The International Journal of Human Resource Management 28/21), 3065-3088. 
Amelina, Anna, Faist, Thomas (2012). De-naturalising the National in Research Methodologies. Ethnic and Racial Studies 35/10, 1-18.

Anderson, Bridget (2010). Migration, Immigration Controls and the Fashioning of Precarious Workers. Work, Employment and Society 24/2, 300-317.

Andrijasevic, Rutvica, Sacchetto, Devi (2016). From Labour Migration to Labour Mobility? The Return of the Multinational Worker in Europe. Transfer: European Review of Labour and Research 22/2, 219-231.

Berntsen, Lisa, Lillie, Nathan (2015). Breaking the Law? Varieties of Social Dumping in a Pan-European Labour Market. Market expansion and social dumping in Europe (ed. Magdalena Bernaciak). London: Routledge, 65-82.

Çaro, Erka, Berntsen, Lisa, Lillie, Nathan, Wagner, Ines (2015). Posted Migration and Segregation in the European Construction Sector. Journal of Ethnic and Migration Studies 41/10, 1600-1620.

Clarke, Stephen, Cominetti, Nye (2019). Setting the Record Straight: How Record Employment has Changed the UK, Resolution Foundation, January.

Coletto, Diego, Fullin, Giovanna (2019). Before Landing: How Do New European Emigrants Prepare Their Departure and Imagine Their Destinations? Social Inclusion 7/4, 39-48.

Cremers, Jan (2011). In search of Cheap Labour in Europe: Working and Living Conditions of Posted Workers. CLR studies 6. Brussels: European Institute for Construction Labour Research.

Danaj, Sonila, Zólyomi, Eszter (2018). Occupational Health and Safety of Posted Workers in the EU: A Comparative Report. POOSH - Occupational Safety and Health of Posted Workers. Dunaj: European Centre for Social Welfare Policy and Research.

De Wispelaere, Frederic, Pacolet, Josef (2018). Posting of Workers. Report on A1 Portable Documents Issued in 2017 (Rep.). Network Statistics FMSSFE, European Commission. Dwyer, Peter James, Scullion, Lisa, Jones, Katy, Stewart, Alasdair (2019). The Impact of Conditionality on the Welfare Rights of EU Migrants in the UK. Policy and Politics 47/1, 133-150.

Ehata, Rebecca, Seeleib Kaiser, Martin (2017). Benefit Tourism and EU Migrant Citizens: Real-world Experiences. Social Policy Review 29, 181-197.

Fihel, Agniezska, Grabowska Lusinska, Izabela (2014). Labour Market Behaviours of Back-and-Forth Migrants from Poland. International Migration 52/1, 22-35.

Fihel, Agniezska, Janicka, Anna, Kaczmarczyk, Paweł, Nestorowicz, Joanna (2015). Free Movement of Workers and Transitional Arrangements: Lessons from the 2004 and 2007 Enlargements. Unpublished Report to the European Commission. Warsaw: Centre for Migration Studies.

Forde, Chris, Slater, Gary (2014). The Effects of Agency Workers Regulations on Agency and Employer Practice. ACAS Research Paper, 01/14.

Heindlmaier, Anita, Blauberger, Michael (2017). Enter at Your Own Risk: Free Movement of EU Citizens in Practice. West European Politics 40/6, 1198-1217. 
Godin, Marie (2020). Far from a Burden: EU Migrants as Pioneers of a European Social Protection System from Below. International Migration 58/1, 136-150.

Houwerzijl, Mijke (2014). Regime Shopping Across (Blurring) Boundaries. Regulating Transnational Labour in Europe: Quandaries of Multilevel Governance (ed. Stein Evju). Oslo: Oslo University Press, 95-130.

Judge, Lindsay (2018). Choices, Choices ... Why do Firms Use Agency Workers? London: Resolution Foundation.

Lee, Chris (2009). Sociological Theories of Immigration: Pathways to Integration for US Immigrants. Journal of Human Behavior in the Social Environment 19/6, 730-744.

Lindstrom, Nicole (2019). What's Left for 'Social Europe'? Brexit and Transnational Labour Market Regulation in the UK-1 and the EU-27. New Political Economy 24/2, 286-298.

Lillie, Nathan (2016). The Right not to have Rights: Posted Worker Acquiescence and the European Union Labour Rights Framework. Theoretical Inquiries in Law 17/1, 39-62.

Marques, Joana, Veloso, Luísa, Sales Oliveira, Catarina (2021). Free Mobility, Locked Rights: The Posting of Construction Workers from Portugal. Mobilities, 1-19.

Massey, Douglas, Malone, Nolan (2002). Pathways to Legal Immigration. Population Research and Policy Review 21/6, 473-504.

McCollum, David, Findlay, Alan (2015). 'Flexible' workers for 'flexible' jobs? The Labour Market Function of A8 Migrant Labour in the UK. Work, Employment and Society 29/3, 427-443.

Novitz, Tonia (2010). UK Implementation of the Posted Workers Directive 96. University of Oslo Working Paper 12.

Portes, Jonathan (2016). Immigration After Brexit. National Institute Economic Review 238/1, R13-R21.

Refslund, Bjarke (2019). Studying Hidden or Hard-to-Access Populations in Case Study Research: The Example of Labour Migrants. SAGE Publications Ltd.

Ryan, Louise, Sales, Rosemary, Tilki, Mary, Siara, Bernadetta (2009). Family Strategies and Transnational Migration: Recent Polish migrants in London. Journal of Ethnic and Migration Studies 35/1: 61-77.

Shutes, Isabel (2016). Work-related Conditionality and the Access to Social Benefits of National Citizens, EU and non-EU Citizens. Journal of Social Policy 45/4, 691-707.

Pemberton, Simon, Scullion, Lisa (2013). The Policies and Politics of Managed Migration: Exploring Mature Labour Migration from Central and Eastern Europe into the UK. Journal of Ethnic and Migration Studies 39/3, 443-461.

Vah Jevšnik, Mojca, Rogelja, Nataša (2018). Occupational Safety and Health in Transnational Workplaces: The Case of Posted Workers. Dve domovini / Two Homelands 48, 23-36.

Wengraf, Tom (2001). Qualitative Research Interviewing: Biographic Narratives and Semi-structured Methods. Sage: London. 


\section{POVZETEK}

\section{MOBILNOST ZNOTRAJ EU: ZAPOSLITVENE IN SOCIALNOZDRAVSTVENE IZKUŠNJE ZAČASNIH DELAVCEV IZ EU V VELIKI BRITANIJI Sonila DANAJ, Erka ÇARO}

Članek obravnava mobilnost začasnih delavcev iz EU in vpliv transnacionalne začasne mobilnosti na njihov uspeh na trgu dela ter dostop do socialnih pravic in ugodnosti. $Z$ analizo petinpetdesetih poglobljenih intervjujev z delavci iz EU na začasnem delu, s socialnimi partnerji in z vodilnimi kadri v Združenem kraljestvu sta avtorici izluščili dva glavna načina zaposlovanja migrantov - napoteno delo in začasno agencijsko delo. Čeprav naj bi bil skupni evropski trg dela načelno brez meja, je dostop do trga dela in socialnih pravic $v$ državah gostiteljicah odvisen predvsem od zaposlitvenega statusa in kriterijev nacionalnega socialnega skrbstva, kar se odraža v različnih življenjskih izkušnjah delavcev.

Ugotovitve raziskave kažejo, da gre pri njihovi pripravljenosti na začasno delo in želji po čim večjem izkoristku napotenega oziroma začasnega agencijskega dela kot dveh poti mobilnosti, pravzaprav za omejeno izbiro. Narekujejo jo potreba po zaslužku, ohranjanju vezi z domovino, kakor tudi potreba po vstopu na trg dela v državi gostiteljici. $V$ teh okoliščinah so delavci bolj dovzetni za izkoriščanje, njihova mobilnost pa je odvisna od njihovega dostopa do socialnega skrbstva. Napotene delavce varuje zakonodaja države pošiljateljice, za agencijske delavce pa je dostop do socialnih ugodnosti države gostiteljice odvisen predvsem od trajanja njihove zaposlitve. Njihov začasni zaposlitveni status se odraža v pomanjkanju pozornosti, ki jo namenjajo svojemu statusu v sistemu socialne oskrbe, kakor tudi v njihovem pomanjkljivem poznavanju svojih delavskih in socialnih pravic. Odločitev Združenega kraljestva, da izstopi iz EU, bo pod pogoji, podobnim točkovnim merilom, ki se uporabljajo za državljane tretjih držav, dodatno omejila mobilnost delavcev iz držav EU, kar lahko privede do različnih oblik razlikovanja in diskriminacije. 